УДК 347.152

DOI https: / / doi.org/10.32837 / yuv.v0i4.982

\author{
В. Васильєв, \\ кандидат юридичних наук, \\ доцент кафедри цивільно-правових дисциплін \\ Східноєвропейського національного університету імені Лесі Українки, \\ докторант кафедри цивільного права № 2 \\ Національного юридичного університету імені Ярослава Мудрого
}

\title{
ЕВОЛЮЦІЯ ПРАВОВИХ ЗАСОБІВ САМОРЕГУЛЮВАННЯ МАЙНОВИХ ЦИВІЛЬНИХ ВІДНОСИН
}

Постановка проблеми. За останне сторіччя юридична наука здійснила стрибок в розробці доктрини правових засобів регулювання суспільних відносин. Однак, незважаючи на це, окремі аспекти піднятої проблеми, зокрема процес еволюції таких засобів, не знайшли комплексного розкриття у працях вчених юристів. 3 точки зору цивільного права і властивого йому диспозитивного методу правового регулювання інтерес викликає проблема засобів саморегулювання майнових відносин і їх місця в генезі засобів правового впливу на суспільні відносини в цілому, що є одним з фундаментальних аспектів юридичної науки.

Аналіз останніх досліджень i публікацій. Сутність та засоби регулювання приватних відносин ставали предметом наукових досліджень, зокрема таких вчених правників як В. К. Антошкіна, В. I. Борисова, Б. Віндшейд, О. М. Гончаренко, Д. Д. Грімм, Г. Дернбург, М. Ф. Казанцев, Л. А. Корунчак, В. В. Кочин, Н. С. Кузнєцова, Р. А. Майданик, I. В. Спасибо-Фатєєва, В. С. Толстой, Б. Б. Черепахін, В. Л. Яроцький та ін.

Мета статті полягає у розгляді сутності основних засобів саморегулювання майнових цивільних відносин i їх інструментальних особливостей в аспекті процесу еволюції.

Основний матеріал дослідження. Перш за все, слід відмітити, що засобами саморегулювання є інстру- менти, які застосовуються учасниками суспільних відносин самостійно для упорядкування зв'язків між собою. Саморегулювання є децентралізованою формою правового регулювання цивільних відносин, яке здійснюється, як правило, актами їх учасників. Протилежною формою правового регулювання таких відносин є централізоване регулювання, яке здійснюється суб'єктом, який наділений правотворчими функціями. Однією з ознак централізованого регулювання є те, що воно здійснюється в односторонньому порядку в рамках реалізації владних функцій.

Незважаючи на те, що визначальну роль в упорядкуванні майнових цивільних відносин відіграють саме правові засоби, повнота розгляду піднятої проблеми може бути досягнута зі зверненням в тому числі до так званих «доправових» інструментів упорядкування відносин. В цьому сенсі в якості первісного способу саморегулювання майнових відносин слід розглядати табу.

1. Табу. Наукове положення про те, що цей засіб став першим нормативним соціальним регулятором суспільних відносин набуло практично догматичного характеру в сучасній юридичній науці. Його нормативність полягала в тому, що табу сприймалось і дотримувалось певною групою осіб протягом тривалого часу. Сутність табу розкривається в науковій літературі через три компоненти: 1) переконаність людей в приналежності до певного колек- 
тиву, що відбивається у розгляді особи, яка порушила заборону, як такої, яка одночасно перебуває в небезпеці і становить небезпеку для інших членів колективу; 2) відчуття страху перед невідомою небезпекою, яку накликають відповідні діі; 3) власне заборона, норма [1, с. 315].

В літературі можна зустріти досить цікаву думку вчених, що в якості одного з перших табу виступила заборона перешкоджати доступу членів групи до мисливської здобичі [1, с. 313] в чому безумовно простежується майновий характер відносин в яких воно застосовувалось. Окреслена ситуація $€$ цікавою з тієї позиції, що вона демонструє природню близькість майнового і немайнового елементів у зв'язках між членами груп у прасуспільстві. Заборона чинити перешкоди в доступі інших членів групи до засобів виживання, якими слугує мисливська здобич, з одного боку забезпечує упорядкування майнових зв'язків між відповідними індивідуумами з приводу визначеного блага, а 3 іншого слугує засобом забезпечення життя відповідних осіб. 3 цього приводу М. М. Бедрій підтримує позицію вчених, відповідно до якої в якості табу також виступали заборони убивати родича, кровозмішення, залишати без допомоги (убивати) слабких і непрацездатних - осіб похилого віку, дітей, осіб з інвалідністю [2, с. 25]. Це дає привід вважати, що табу формується як реакція прасуспільства на загрози навколишнього світу i спрямовується перш за все на підвищення рівня виживання відповідної групи. При цьому, в цій спрямованості табу охоплює як зв'язки між членами прасуспільства стосовно майнових, так і немайнових благ.

В літературі можна зустріти думку, що табу в певній мірі ззовні нав'язувалось первісній людині [3, с. 22-23], з чим, однак, важко погодитись. Встановлення заборон $є$ реакцією відповідних груп на зовнішні загрози. При цьому, такі загрози не можна розглядати в якості фактору, що обумовлює зовнішне нав'язування заборон відповідним особам. Джерелом табу виступав страх перед невідомим. Не існувало цілеспрямованої влади як інструменту встановлення табу. Вони формувались відповідними індивідуумами самостійно як реакція на зовнішні небезпеки i сприймались практично всіма членами групи в чому знаходить прояв ї самоорганізація, а також нормативність відповідного регулятора.

2. Правовий звичай. Проблема правових звичаїв знайшла широке розкриття у працях XIX ст. німецьких вчених пандектистів. Зокрема, Б. Віндшейд зазначав, що під звичаєвим правом розуміється те право, що не будучи встановленим державою, дотримується фактично. При цьому, на думку вченого, в такому дотриманні знаходить прояв переконаність осіб, які дотримуються відповідних правил, у тому, що вони i є право. Ця переконаність $є$ основою зобов'язальної сили звичаєвого права, оскільки свідомість народу $€$ джерелом будь-якого позитивного права [4, с. 37-38]. У свою чергу, Г. Дернбург, визнаючи звичай найстарішим джерелом права, вважав, що саме на звичаях базуються основні інститути цивільного права - власність, шлюб, спорідненість [5, с. 66]. В подальшому думка, згідно 3 якою положення звичаєвого права виникають в результаті одноманітного застосування певної норми протягом тривалого часу з впевненістю в їі юридичній силі [6, с. 63], стала пануючою в розкритті сутності правового звичаю.

В сучасній юридичній літературі відносно часто висловлюється думка про те, що в додержавний період правовий звичай виступав єдиним джерелом права, в той час як табу являли собою соціальні норми [2, с. 24-25]. Поряд із цим, вважаємо, що повністю погодитись $з$ цим не можна. Табу як первісний регулятор суспільних зв'язків виступав одним із факторів формування звичаю. Хоча табу і формувались в певній мірі хаотично, тим не менше, вони базувались на певних раціональ- 


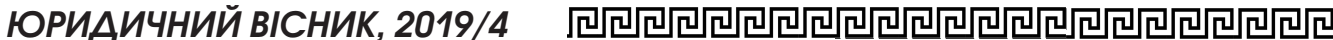

них на той час факторах. Не все було заборонено. При цьому окремі заборони «приживались» у певній групі, а інші ні. У свою чергу звичай $€$ усталеним правилом поведінки. Це дає привід вважати, що табу, виступаючи первісним доправовим засобом упорядкування в тому числі майнових відносин створив фундамент для формування звичаю як більш прогресивного вже правового, а не лише соціального, засобу, якому властиві не лише заборони, а й дозволи і навіть позитивні зобов'язування. Тут же простежується і автономізація звичаю від табу. Суспільство може не пам'ятати чому була встановлена первісна заборона певної поведінки, однак приймати відповідне правило в основу якого покладено заборону, в якості загальноприйнятого.

Історичний період формування правового звичаю як джерела права тісно пов'язується $з$ проблемою виникнення права в цілому. Цей зв'язок чітко простежується в розмежуванні соціального i правового звичаїв як можливих різних етапів розвитку відповідного регулятора. «Можливих», тому що, не всі звичаї набували правового характеру, а ті, що набували, перед цим були звичаями соціальними.

Не заглиблюючись в проблему співвідношення права і держави, слід погодитись 3 вченими, які вважають, що позитивне право склалось при переході людства до цивілізаціі, коли виникли об'єктивізовані основи для свобод окремої людини - поява надлишкового продукту у вигляді приватної власності [7, с. 39]. На заміну егалітарної традиціï розвиненого первісного суспільства все більше приходило визнання правомірності майнової і соціальної диференціації членів суспільства, ї нерівного доступу до матеріальних i духовних цінностей, спадковий характер такої нерівності 3 чим, зокрема пов'язувалось і створення нової норми - правової [8, с. 227]. Процес такої диференціації, а також формування в ході міжплемінних конфліктів, зокрема військової еліти, сприяли утворенню більш складної організації міжплемінних і внутрішньоплемінних стосунків, що, у свою чергу, стимулювало процес інституціоналізації влади. Результатом цього став поступовий перехід від самоврядності первісної общини до формування публічної політичної влади з високим рівнем організованості в рамках якої виокремлювались окремі інституції, які наділялись, зокрема і нормотворчими функціями. Як зазначають теоретики права, право спочатку існувало у вигляді схвалених державою фактичних, повторюваних суспільних відносин, які набували правового характеру. 3 часом воно закріплюється і виражається в письмових, офіційних джерелах - законах, судових прецедентах, нормативних договорах, тощо [9, с. 73], які стають основним засобом нової форми регулювання суспільних відносин, в тому числі майнових, - централізованої. В якості перших законодавчих пам'яток наразі розглядаються Закони Хаммурапі (приблизно 1780 1750 роки до н.е.), а також Закони Ману (приблизно II ст. до н.е. - II ст. н.е.) $[10$, с. 13-14]. Формування приватного (цивільного) права як цілісного системного нормативного утворення, на переконання деяких вчених, відбувалось у I ст. н.е. [11, с. 65]. У зв'язку 3 цим, можна стверджувати, що саме з цього часу відповідні правові засоби саморегулювання набувають власне цивільно-правового характеру в сучасному розумінні, тобто стають звичаями цивільно-правовими.

Зважаючи на викладене вище, очевидно, що звичай як засіб регулювання майнових відносин виник раніше за нормативно-правовий акт, що дає привід вважати, що навіть при виникненні права саморегулювання виступало первісною формою упорядкування суспільних відносин, в тому числі майнових. При цьому, правовий звичай як засіб саморегулювання майнових відносин має перехідний характер. В процесі інституціоналізаціі влади соціальний звичай набуває правового характеру і стає відповідно звичаєм правовим. 
3. Договір. Цей засіб саморегулювання майнових цивільних відносин став найбільш прогресивним. Його перевагами $€$ те, що він здатен індивідуально регулювати відносини практично у будь-якій сфері суспільного виробництва. Єдиним обмеженням договору є його відносний характер. Як правило, він $є$ обов'язковим лише для тих осіб, які його укладають та їх правонаступників.

Наукові дослідження не дають змогу достеменно встановити часові межі виникнення договору як засобу упорядкування суспільних відносин. В сучасній юридичній літературі відмічається, що договір використовувався на всіх етапах правової еволюції. При цьому приватноправовий договір виник на зорі державно-правового розвитку для вчинення майнових правочинів, встановлення шлюбних відносин [12, с. 52].

3 матеріалістичної точки зору значним фактором розвитку договірних форм регулювання майнових відносин виступило виникнення власності [13, с. 83] i, зокрема приватної власності [14, с. 18]. Як ми зазначали, одні 3 перших табу майнового характеру безпосередньо пов'язувались 3 привласненням благ. Поряд із цим лише після виникнення надлишків майнових благ виникає необхідність в застосуванні окремого засобу, який дозволяє розпоряджатись ними на корить інших осіб для отримання взамін благ іншого характеру, тобто для забезпечення товарообмінних операцій. Зважаючи на те, що ані табу, ані звичай не були наділені необхідними якостями, які б дозволяли налагоджувати договірні відносини з урахуванням індивідуальних особливостей ситуації саме договір починає займати місце основного засобу саморегулювання майнових відносин, яке і в умовах сьогодення почесно належить йому.

Індивідуальний характер регулювання суспільних відносин, що властивий цивільно-правовому договору, дозволяє стверджувати про те, що елементи домовленості простирають свої корені глибоко в історію формування людства. Що, по суті, є табу як не спільна згода членів прасуспільства в утриманні від повної поведінки? I що таке звичай, як не правило поведінки, що формувалось в тому числі шляхом тривалого встановлення однотипних моделей суспільних зв'язків учасниками договірних відносин?

Набуття договором статусу найбільш ефективного і гнучкого регулятора суспільних відносин відбувалось поступово по мірі розвитку суспільства і ускладнення суспільних зв'язків на що не могли оперативно реагувати ані табу, ані звичаї, ані нормативно-правові акті, ані жодні інші засоби. Це демонструється і тією обставиною, що норми про договір як засіб регулювання відносин купівлі-продажу, оренди, підряду тощо знайшли закріплення на рівні приписів перших пам'яток права, в тому числі Законів Хаммурапі.

4. Односторонні акти як правові засоби саморегулювання майнових цивільних відносин завдячують своїм виникненням еволюції майнових відносин, а також форм кооперації суб'єктів цивільного права. Ці засоби виникли в останню чергу, оскільки для їх використання необхідні специфічні умови, зокрема високий рівень організованості суспільства і ринкових відносин.

Вже перші об'єднання громадян, які утворювались для спільного ведення певних справ, в тому числі з метою отримання прибутку, передбачали закріплення обов'язкових для їх учасників правил поведінки, що стосувались в тому числі порядку здійснення майнових витрат і розподілу доходів. Відповідаючи на вимоги суспільства римське право запропонувало нову конструкцію - universitates (юридичні особи), яка передбачала наділення правами приватних осіб професійних і релігійних союзів (collegia, sodalicia, societates, corpora), самоврядних місцевих цивільних громад (minicipia, colonie), державної казни (fiscus) [15, с. 297]. В якості одного із засобів регулювання майнових і організацій- 


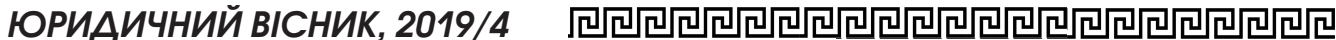

них відносин між учинками відповідних утворень виступав цивільно-правовий договір, гнучкість якого як інструмента упорядкування суспільних зв'язків повністю задовольняла потреби суспільства. Зокрема, прообраз сучасних господарських товариств - societas утворювався шляхом укладення договору між його учасниками [15, с. 441].

Поряд із цим, еволюція уявлень про конструкцію юридичної особи сприяла переосмисленню проблеми правових засобів регулювання порядку здійснення діяльності відповідним утворенням. Визнання можливості створювати юридичну особу одним учасником унеможливило використання договору як регулятора організаційних і майнових відносин всередині неї. Це сприяло виникненню нового засобу саморегулювання майнових відносин - статуту.

Крім того, формою саморегулювання майнових цивільних відносин на ранніх етапах розвитку цивільного права стали засоби, які мали окремі ознаки договорів, однак використовувались в односторонньому порядку. Ними виступили односторонні акти, зокрема такі як публічна обіцянка винагороди. Особа самостійно в односторонньому порядку моделює зміст цивільних правовідносин, наприклад, формує завдання i визначає винагороду за його виконання, й у визначеній формі адресує пропозицію вступити в ці правовідносини іншим особам. Свідомо здійснюючи поведінку, що кореспондує пропозиції, інші особи вступають у відповідні правовідносини. Процес виникнення правовідносини відрізняє відповідні правові засоби від договору.

Також в якості засобу саморегулювання майнових цивільних відносин, що застосовуються в односторонньому порядку, можна віднести окремі види цінних паперів, а також актів, що вчиняються в процесі їх емісії (видачі) і фіксуються у визначеній формі. Серед сучасних прикладів таких актів виступає, зокрема оформлення проспекту облігацій, який містить в тому числі інформацію про ціну розміщення відпо- відних цінних паперів і розмір доходу за відсотковими облігаціями [16, п. 5 розділу II].

В цілому поява односторонніх актів індивідуального саморегулювання майнових цивільних відносин $€$ результатом розвитку останніх, еволюціі цивільного обороту в цілому і, зокрема виникнення необхідності використання інструментів упорядкування суспільних зв'язків, процес формування яких на ранній стадії передбачає ідентифікацію лише одного учасника відносин, який і використовує відповідний інструмент правового регулювання. Вступ іншого суб'єкта (суб'єктів), особа якого може бути невідомою на момент вчинення акту саморегулювання, відбувається відтерміновано відносно такого моменту.

Висновки і перспективи подальших досліджень. Узагальнюючи викладене вище, необхідно визнати, що в процесі еволюції людства саморегулювання виступило первісною формою упорядкування суспільних відносин. Засоби впливу, що забезпечували досягнення відповідної мети, за своїм якісним рівнем відповідали рівню розвитку суспільства, однак, що головне, формувались самим суспільством для регулювання власної ж поведінки. Відповідний інструментарій пройшов значний шлях еволюції від табу як примітивного відносного сучасності доправового засобу регулювання поведінки, до договору, як універсального інструменту регулювання цивільних відносин. При цьому майновий компонент відігравав вкрай важливу роль у відповідному еволюційному процесі причини чому криються у потужному впливі розвитку відносин власності на розвиток людства в цілому.

Особливістю засобів саморегулювання майнових цивільних відносин $€$ те, що вони могли і можуть існувати та застосовуватись одночасно в рамках єдиної правової системи. Це пов'язується, зокрема 3 різним ступенем ї юридичної гнучкості, а тому і різним характером впливу на учасників май- 
нових цивільних відносин. При цьому плюралізм засобів індивідуального саморегулювання відповідних суспільних зв'язків, зокрема тих, що застосовуються в односторонньому або двосторонньому порядку, забезпечується адаптацією до типових правових ситуацій, а тому і ефективністю у виконанні регулятивної функції.

Стаття присвячена розгляду сутності основних засобів саморегулювання майнових изивільних відносин $i$ ї інструментальних особливостей в аспекті процееу еволюиї.

Встановлюеться, щио периим нормативним соціальним регулятором суспільних відносин в доправову епоху виступило табу як заборона певної поведінки. При цьому в юридичній літературі висловлюється думка, шо однією з перших сформувалась заборона перешкоджати доступу членів групи до мисливської здобичі. Автор формує висновок, що джерелом табу виступав страх перед невідомим. Відповідні заборони формувались індивідуумами самостійно як реакція на зовнішні небезпеки в чому знаходили прояв їх самоорганізація і нормативність відповідного регулятора.

Визначається, що табу стало передумовою формування звичаю як усталеного правила поведінки. При изьому еволюиія звичаю демонструє те, шьо засоби саморегулювання майнових відносин випередили виникнення засобів їх иентралізованого регулювання. До виникнення права звичай мав соиіальний характер $i$ вже виступав інструментом упорядкування суспільних зв'язків майнового характеру. У свою чергу формування права як феномену надало певним звичаям правового характеру, оскільки на ранніх стадіях розвитку держав саме звичай отримав офіційне визнання. Лише згодом державні утворення почали активно використовувати нормативно-правові акти для регулювання майнових вїносUн.
Виникнення договору пов'язують з виникненням приватної власності. Встановлюеться, що цей засіб саморегулювання майнових циивільних відносин став найбільш прогресивним. Його перевагами є те, що він здатен індивідуально регулювати практично будь-які відносини.

Aвтор доходить висновку, що формування односторонніх актів як засобів саморегулювання майнових иивільних відносин супроводжувалось розвитком конструкціі юридичних осіб. Однак, в подальшому виникли нові інструменти правового регулювання одностороннього характеру, які врегульовували відносини, що в силу специфіки не могли упорядковуватись договором.

Ключові слова: саморегулювання, самоорганізація, табу, звичай, договір, акти одностороннього характеру, майнові відносини

\section{Vasyliev V. EVOLUTION OF LEGAL MEANS OF SELF- REGULATION OF PROPERTY CIVIL RELATIONSHIPS}

The article is devoted to consideration the essence of main means of self-regulation of property civil relationships as well as their instrumental features in context of evolution.

It's defined that taboo as prohibition of some behavior became the first normative social regulator of relations in pre-legal period. In addition according to some scientist's opinion first taboo was the rule that prohibited blocking of group members access to hunter's booty. The author concludes that fear of unknown became the first source of taboo. Appropriate prohibitions have been formulating by individuals themselves as reaction on external danger that can be qualified as signs of self-organization and normativity of appropriate regulator.

It's determined that taboo has become the prerequisite of the formation of custom as established rule 


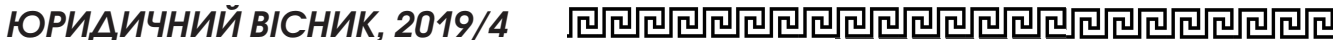

of conduct. Besides, the evolution of a custom demonstrates that means of selfregulation of property relationships had outpaced the origination of the means of centralized regulation. Before law originated the custom had been used as instrument of arrangement of social connections of proprietary character. In its turn emergence of law as phenomenon transformed customs to legal means, since at the early stages of state evolution barely custom got official recognition. Only later state formations began to use legislative acts for regulation property relationships.

The emergence of the contract is associated with emergence of private property. It's defined that this mean of self-regulation of property relationships has become one of the most progressive. Its advantage is that it can be used for regulation almost any relationships.

The author concludes that emergence of unilateral acts as means of selfregulation of property civil relationships has been accompanying by evolution of the construct of legal entity. But later new unilateral instruments of legal regulation emerged because some property relationships were not be able to be regulated by contract because of their features.

Key words: self-regulation, selforganization, taboo, custom, contract, unilateral acts, property relationships

\section{Література}

1. История первобытного общества: в 3 m. / отв. ред. Ю. В. Бромлей. Москва: Изд-во «Наука», 1983. Т. 1: Общие вопросы. Проблемь антропосоциогенеза. 432 c.

2. Бедрій М. М. Правовий звичай у первісному (додержавному) суспільстві: окремі акценти. Часопис Київ. ун-ту права. 2016. № 2. C. 24-27.

3. Сильченко H. В. Зарождение первичных закономерностей нормативного регулирования общественных отноше ний. Государство и право: теория и практика. Вып. 3. Калининград: Изд-во КГУ, 2004. C. 22-35.

4. Виндшейд Б. Учебник пандектного права: в $3 \mathrm{~m}$. / пер. с нем. под. ред. С. В. Пахмана. Санкт-Петербург: Изд.
Иероглифова и Никифорова, 1874. T. 1: Обшая часть. XIV, $358 \mathrm{c}$.

5. Дернбург Г. Пандекть: в $3 \mathrm{~m}$. / пер. Г. фон Рехенберга под. рук. П. Соколовского. Москва: Университет. типогр., Страстной бульвар, 1906. Т. I: Общая uacmb. XVI, 465 c.

6. Регельсбергер Ф. Общее учение о праве / пер. И. А. Базанова; под ред. проф. Ю. С. Гамбарова. Москва: Типогр. Высоч. учрежд. Т-ва И. Д. Сытина, 1897. 295 с.

7. Луиький Р. П. Позитивне право та природне право: опозиція категорій. Часопис Київ. ун-ту права. 2011. № 4. С. 38-41.

8. История первобытного общества: в 3 m. / отв. ред. Ю. В. Бромлей. Москва: Изд-во «Наука», 1988. Т. 3: Эпоха классообразования. 565 с.

9. Загальна теорія держави і права: підруч. для студ. юрид. вищ. навч. закладів / М. В. Цвік та ін.; за ред. д-ра юрид. наук, проф. академіка АПрН України М. В. Цвіка, д-ра юрид. наук, проф. академіка АПрН України О. В. Петришина. Харків: Право, 2009. 584 с.

10. Чалая Л. А., Лядова А. В. История договорного права: учеб. пособие. Владимир: Изд-во Владимир. гос. ун-та, 2008. $172 \mathrm{c}$.

11. Майданик Р. Цивільне право як сфера приватного права України. Приватне право. 2013. № 1. С. 65-80.

12. Каманина T. В. Эволюиия форм права. Lex Russica. 2011, № 1. C. 34-53.

13. Медениев П. А. Еволюиія правового регулювання договірних зобов'язань $і$ відмови від їх виконання в України та окремих зарубіжних країнах. Вісн. Одеськ. наи. ун-ту ім. I. I. Мечникова. Одеса: Астропринт, 2008. T. 13, вип. 10. Сер. «Правознавство». С. 83-88.

14. Бабаев М. Я. История возникновения и развития договора как инструмента права. Образование. Наука. Научные кадры. 2019. № 2. С. 17-19.

15. Дождев Д. В. Римское частное право: учебник для вузов / под общ. ред. акад. РАН, д.ю.н., проф. В. С. Нерсесяниа. 2-е изд., изм. и доп. Москва: Норма, 2006. $784 \mathrm{c}$

16. Положення про порядок здійснення емісії облігацій підприємств та їх обігу: затверджено рішенням Національної комісії з иінних паперів та фондового ринку від 21.06 .2018 р. № 425, зареєстрованим в Міністерстві юстииї України 19.07.2018 p. за № 843/32295. Офіи. вісн. України. 2018. № 63. Ст. 2188 (із змінами). 